\title{
BIOGAS POTENTIAL OF DIGESTATE AFTER FERMENTATION OF SIDA HERMAPHRODITA SILAGE
}

Paulina RUSANOWSKA, Department of Environment Engineering, Faculty of Environmental Science, University of Warmia and Mazury in Olsztyn, Warszawska 117, 10-720 Olsztyn, Poland, paulina.jaranowska@uwm.edu.pl, (corresponding author)

Magda DUDEK, Department of Environment Engineering, Faculty of Environmental Science, University of Warmia and Mazury in Olsztyn, Warszawska 117, 10-720 Olsztyn, Poland, magda.dudek@uwm.edu.pl

Marcin ZIELIŃSKI, Department of Environment Engineering, Faculty of Environmental Science, University of Warmia and Mazury in Olsztyn, Warszawska 117, 10-720 Olsztyn, Poland, marcin.zielinski@uwm.edu.pl

Marcin DĘBOWSKI, Department of Environment Engineering, Faculty of Environmental Science, University of Warmia and Mazury in Olsztyn, Warszawska 117, 10-720 Olsztyn, Poland, marcin.debowski@uwm.edu.pl

Lignocellulosic biomass is one of the most widely used substrate in methane digestion. Among plants with a high yield potential, Sida hermaphrodita is particularly noteworthy, due to Sida can be grown on low quality soils and its utilization for energy purposes is not competitive with food crops. Methane fermentation of biomass with such a complex structure usually requires application of pretreatment methods for efficient utilization of its cellulose and hemicellulose. It is economically justified to control of digestate if substrate was efficiently used. The study aimed to measure biogas potential of digestate after fermentation of Sida hermaphrodita silage. The post-fermentation of two samples of digestate from the reactors operated at organic compounds loading $2 \mathrm{~kg} /\left(\mathrm{m}^{3} \cdot \mathrm{d}\right)-\mathrm{S} 1$ and $3 \mathrm{~kg} /\left(\mathrm{m}^{3} \cdot \mathrm{d}\right)-\mathrm{S} 2$ was performed. Hydraulic retention time in these reactors was $50 \mathrm{~d}$ and $33 \mathrm{~d}$, respectively. Biogas potential of fermented sludge was measured with the use of AMPTS II (Bioprocess control). Biogas production was $0.012 \mathrm{~L} / \mathrm{g}$ TS and $0.031 \mathrm{~L} / \mathrm{g}$ TS from digestate's S1 and S2, respectively. The methane content in biogas was $15 \%$ from digestate S1 and $50 \%$ from digestate S2. The obtained results suggest that digestate from reactor with organic compounds loading of $3 \mathrm{~kg} /\left(\mathrm{m}^{3} \cdot \mathrm{d}\right)$ still has high biogas potential, and hydraulic retention time in this reactor should be prolonged.

Keywords: hydraulic retention time, organic compounds loading, post-fermentation, Sida hermaphrodita silage,

\section{INTRODUCTION}

Digestate is a methane fermentation residue that contains valuable nutrients (nitrogen, phosphorus and potassium) in plant available forms. Therefore, instead of treating digestate as a waste, in recent years, many efforts have been made to use it for land applications such as soil amendment or fertilizer (Chambers and Taylor, 2013). However, due to odors, pathogens and heavy metals the use of digestate as fertilizer can contribute to environmental pollution.

Non-renewable fossil resources are still a large fraction of the world's total energy derivers (more than 84\%). Biogas produced by methane fermentation of renewable feedstocks is considered as one of the alternatives to fossil fuels. Agricultural residues, energy crops, forestry residues and yard trimmings consist of lignocellulosic biomass. The methane fermentation of lignocellulosic biomass and organic waste as energy sources for the production of biogas (or biomethane) in the anaerobic digestion process has attracted much attention in most countries (Dhanya et al., 2013). The lignocellulosic biomass has a good potential for biogas production. To minimize competition with food production, the choice of substrates for methane fermentation is mainly determined by their availability and should be based on the utilization of non-food biomass including Sida hermaphrodita. Among energy crops and crop residues, Sida hermaphrodita is particularly noteworthy. Sida does not require any special soil conditions, it has the ability to store carbon in its highly branched root system, and its biomass has low moisture content at harvest (Borkowska and Molas, 2012).

Methane yields of lignocellulosic biomass are relatively low due to the recalcitrance of the plant cell wall to digestion. Plant cell walls are mainly composed of cellulose (9-80\%), hemicellulose (10-50\%), and lignin (5-35\%) along with small amounts of other organic compounds such as proteins, lipids and minerals (Frigon and Guiot, 2010; Cheng et al., 2011). The cross-linking among cellulose, hemicellulose, and lignin results in a rigid three-dimensional matrix, which is a barrier for liquid penetration and enzyme access, thus impeding digestion of lignocellulosic biomass (Khanal, 2008). The complex structure of lignocellulosic materials is known to be a crucial obstacle for transition from traditional cereal crops to lignocellulosic feedstock. However, in recent years there has been a dynamic development of different methods of structural digestion and recovery of lignin-encrusted sugars (Zheng et al., 2014).

Copyright (C) 2017 The Authors. Published by Aleksandras Stulginskis University. This is an open-access article distributed under the terms of the Creative Commons Attribution License (CC-BY 4.0), which permits unrestricted use, distribution, and reproduction in any medium, provided the original author and source are credited. 
Methane fermentation of Sida hermaphrodita silage, due to high total solids (TS) content and low biodegradability requires optimization of organic compounds loading. Moreover, the high solid content leads to slow mass transfer between microbes and feedstocks, resulting in slow methane production and low methane yield. The efficiency of methane fermentation decreased by about $60 \%$ when total solids increased from $20 \%$ to $30 \%$ (Le Hyaric et al., 2011; Forster-Carneiro et al., 2007). Therefore, longer retention time is needed to digestion of organic substances contained in the lignocellulosic biomass. For these reasons, comprehensive digestate tests are required so that its use as fertilizer does not contribute to greenhouse gas emissions. Given the potentially large number of organic contaminants and their degradation products in digestate, more studies are needed to examine their long-term effects on environment. In this study, we have determined the biogas potential of digestate after fermentation of Sida hermaphrodita silage. The post-fermentation of two samples of digestate from the reactors operated at different organic compounds loading was performed.

\section{MATERIALS AND METHODS}

\section{Methane fermentation of post-digestion sludge}

In the study, the biogas potential of post-digestion sludge was examined. The digestate was obtained from bioreactor with methane fermentation of Sida hermaphrodita silage. The bioreactor had innovative design mixing cage system (Fig. 1). The bioreactor was a tubular tank with internal diameter of $1.2 \mathrm{~m}$ and height of $0.4 \mathrm{~m}$. The active volume of the bioreactor was $339 \mathrm{~L}$. The operating height of $0.3 \mathrm{~m}$ was filled with anaerobic sludge. Above, the gas phase was present, in which biogas was collected. In order to provide anaerobic conditions, the reactor was closed with a dome, which the side walls were located below the liquid level in the reactor. Mixing system of the reactor consisted of two cylindrical stirrers in the form of cage with diameter of $0.35 \mathrm{~cm}$. The cages by rotation around the axis of the reactor at the same time turn against its own axis.

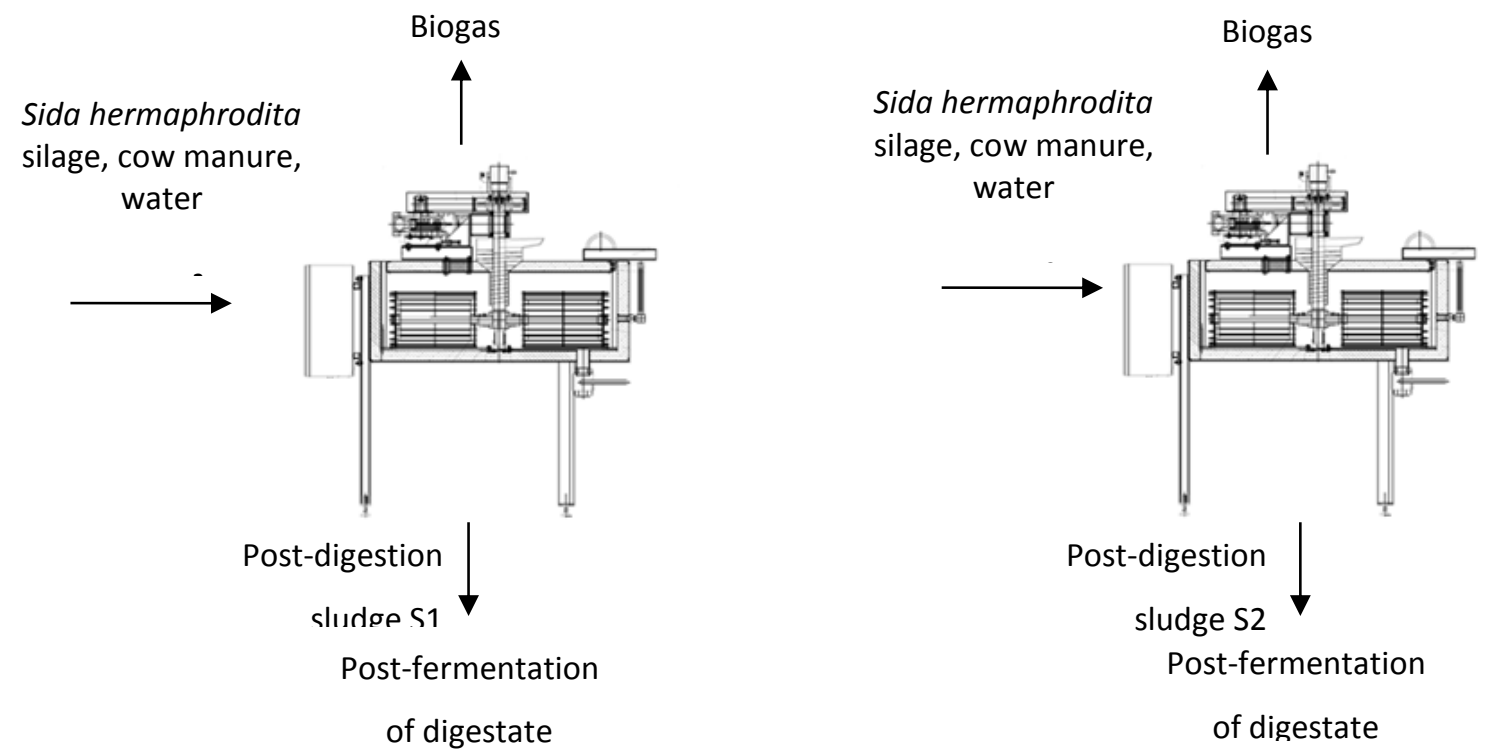

Figure 1. Scheme of the experiment

The substrate used in the study was Sida hermaphrodita silage. The average value of TS in the silage was $28 \%$, volatile solids (VS) constituted $92.2 \%$ of TS and ash constituted $6.8 \%$ of TS, total nitrogen (TN) was $0.005 \mathrm{~g} / \mathrm{g}$, and COD was $1.547 \mathrm{~g}$ $\mathrm{O}_{2} / \mathrm{g}$ TS. The average value of total carbon (TC) was $0.413 \mathrm{~g} / \mathrm{g}$, and that of total organic carbon (TOC) was $0.382 \mathrm{~g} / \mathrm{g}$. To increase the moisture content, a cow manure mixed with fresh water was added to the silage. The substrate was crushed before being introduced into the bioreactor. The bioreactors were operated at organic compounds loading $2 \mathrm{~kg} /\left(\mathrm{m}^{3} \cdot \mathrm{d}\right)-\mathrm{S} 1$ and 3 $\mathrm{kg} /\left(\mathrm{m}^{3} \cdot \mathrm{d}\right)-\mathrm{S} 2$. Hydraulic retention time in these bioreactors was $50 \mathrm{~d}$ and $33 \mathrm{~d}$, respectively. The average daily biogas production was 830.1 L in S1 and 973.4 L in S2. The methane content in biogas produced in both bioreactors was about $54 \%$.

The biogas potential of digestate obtained from bioreactors operated at both values of organic compounds loading was tested. The study was carried out in the methane potential analysis tool (AMPTS II Bioprocess Control). This device was used to measure the quantity of biogas produced. Reactors of the volume of $500 \mathrm{~mL}$ were connected to the multifunctional agitation system. Mixing in the reactor run for 30 seconds each 10 minutes. Rotating speed was $100 \mathrm{rpm}$. The $200 \mathrm{~mL}$ of digestate was introduced to the reactors. Anaerobic conditions were achieved by continuous flushing of pure nitrogen through the sludge. Methane fermentation was carried out under mesophilic conditions at $37^{\circ} \mathrm{C}$ for 40 days. The experiments were performed in triplicates.

\section{ANALYTICAL METHODS}

In the samples of digestate introduced to the AMPTS II and in the samples after post-fermentation the $\mathrm{pH}$, the FOS/TAC ratio (explained below), the TS and VS, and the total organic carbon (TOC) and total nitrogen (TN) were 
determined. The quantity of biogas was measured with the AMPTS II. The quality of biogas was measured with an LXI 430 analyzer (GasData) and by using a gas chromatograph connected with thermal conductivity detector (GC-TCD) (Agillent 7890 A). The FOS/TAC ratio was determined with TitraLab AT1000 Series Titrator (Hatch). The TAC value is an estimation of the buffer capacity of the sample, and the FOS value indicates the volatile fatty acids content. The biomass samples were tested for the content of TS and VS with a gravimetric method. The concentration of TN and TOC were measured with TOCL, Schimatzu. After testing for homogeneity of variance with Levene's test, the significance of differences between variants was tested with Tukey's HSD test. Differences were considered significant at $\mathrm{p}<0.05$.

\section{RESULTS AND DISCUSSION}

The total solids content in the digestate S1 was $10 \%$ lower than in the digestate S2 (Fig. 2A). The same tendency was observed after post-fermentation. The volatile solids were $74 \%$ in TS in the digestate from the reactor with organic compounds loading $2 \mathrm{~kg} /\left(\mathrm{m}^{3} \cdot \mathrm{d}\right)$ and $78 \%$ in TS in the digestate from the reactor with organic compounds loading 3 $\mathrm{kg} /\left(\mathrm{m}^{3} \cdot \mathrm{d}\right)$. After post-fermentation in the both reactors, VS was $70 \%$ of TS. The higher TS concentration in the digestate S1 was caused by higher daily dose of Sida hermaphrodita silage to the reactor. In case of the S1 daily dose was $4.5 \mathrm{~kg}$ of Sida hermaphrodita silage, whereas in case of the S2 daily dose was $6 \mathrm{~kg}$ of Sida hermaphrodita silage.

The TOC in the digestate from the reactor with organic compounds loading $3 \mathrm{~kg} /\left(\mathrm{m}^{3} \cdot \mathrm{d}\right)$ was almost twice time higher than in the digestate from the reactor with organic compounds loading $2 \mathrm{~kg} /\left(\mathrm{m}^{3} \cdot \mathrm{d}\right)$ (Fig. 2B). The efficiency of removal of the TOC in the both reactors after post-fermentation was similar. The TN in the digestate S2 was only $22 \%$ higher than in the digestate S1. The efficiency of removal of the TN in the both reactors was about $50 \%$.
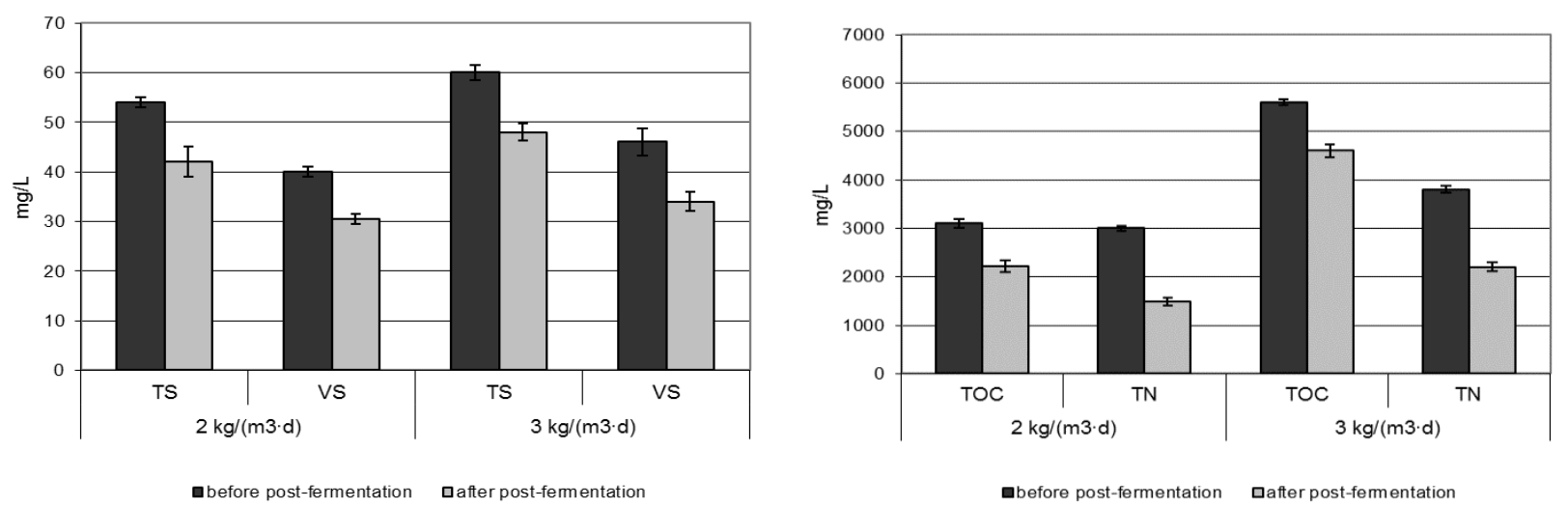

Figure 2. The concentration of A) total solids (TS), volatile solids (VS), and B) total organic carbon (TOC), total nitrogen (TN) before and after post-fermentation

The biogas production during post-fermentation was $0.012 \mathrm{~L} / \mathrm{g}$ TS and $0.031 \mathrm{~L} / \mathrm{g}$ TS from the digestate's S1 and $\mathrm{S} 2$, respectively. The methane content in biogas was $15 \%$ from the digestate $\mathrm{S} 1$ and $50 \%$ from the digestate $\mathrm{S} 2$. The $\mathrm{pH}$ and the FOS/TAC ratio are methane fermentation indicators (Table 1). Stable biogas production usually takes place at a $\mathrm{pH}$ between 7-8 and a FOS/TAC ratio below 0.4 (Drosg, 2013). At pH values below 7, the activity of the microorganisms that degrade volatile fatty acids is lower, which reduces biogas production. Despite production of volatile fatty acids, the $\mathrm{pH}$ was still high and did not restrict methane fermentation. Buffer capacity did not change significantly during the processes. However, the FOS value after post-fermentation dropped of about $30 \%$ in the both reactors. The higher FOS content in the digestate $\mathrm{S} 2$, proved that in this reactor there was not enough time for utilization of all volatile fatty acids formed during the process.

Table 1. The FOS/TAC ratio, the volatile fatty acids content, the buffer capacity and the $\mathrm{pH}$ in the samples before and after postfermentation

\begin{tabular}{|c|c|c|c|c|c|}
\hline & Samples & FOS/TAC ratio & FOS $\left(\mathrm{mg} \mathrm{CH}_{3} \mathrm{COOH} / \mathrm{L}\right)$ & TAC $(\mathrm{mg} / \mathrm{L})$ & $\mathrm{pH}$ \\
\hline \multirow{2}{*}{$2 \mathrm{~kg} /\left(\mathrm{m}^{3} \cdot \mathrm{d}\right)$} & Before post-fermentation & $0.19 \pm 0.02$ & $2508 \pm 98$ & $13213 \pm 123$ & $8.17 \pm 0.01$ \\
\cline { 2 - 6 } & After post-fermentation & $0.13 \pm 0.03$ & $1848 \pm 79$ & $13770 \pm 155$ & $8.21 \pm 0.01$ \\
\hline \multirow{2}{*}{$3 \mathrm{~kg} /\left(\mathrm{m}^{3} \cdot \mathrm{d}\right)$} & Before post-fermentation & $0.24 \pm 0.01$ & $3325 \pm 101$ & $13854 \pm 101$ & $7.97 \pm 0.03$ \\
\cline { 2 - 6 } & After post-fermentation & $0.19 \pm 0.02$ & $2260 \pm 84$ & $13250 \pm 101$ & $8.02 \pm 0.04$ \\
\hline
\end{tabular}

Almost all process indicators showed that organic compounds loading of $3 \mathrm{~kg} /\left(\mathrm{m}^{3} \cdot \mathrm{d}\right)$ was too high for economically and environmentally justified methane fermentation process. Despite higher biogas production in this bioreactor, the digestate utilization should be considered before selecting of operation parameters of methane fermentation.

The digestate can be separated into liquid and solid streams. The solid stream consist of suspended solids and undigested residues. Depending on a substrate type and operating conditions of the digester, the composition of solid residue varies. The obtained results suggest that the digestate from bioreactor with organic compounds loading of 3 $\mathrm{kg} /\left(\mathrm{m}^{3} \cdot \mathrm{d}\right)$ still has high biogas potential, and solids retention time in this bioreactor should be prolonged. The study of 
Klimiuk et al. (2010) showed the influence of efficiency of different lignocellulosic biomass composition on methane fermentation. The volumetric methane yields from Zea mays L. or Sorghum saccharatum silages were higher than those from Miscanthus $\times$ giganteus or Miscanthus sacchariflorus silages because of higher lignin content in Miscanthus. The results indicate that anaerobic digestion of Miscanthus silages under mesophilic conditions needs longer HRT than $60 \mathrm{~d}$ or applying methods of lignin-encrusted sugars recovery. By carefully adjusting the solids retention time, the fermentation might have ability to promote methane production from hemicellulose exclusively, while leaving behind cellulose and lignin in the fibrous solid residue. For this reason, high organic compounds concentration still characterize digestate. It is important to prevent this situation during methane fermentation.

There are several ways to manage with post-digestate sludge. The digestate might be recycled to the bioreactor. Moreover, the digestate could be used for the production of bio-oil and biochar via pyrolysis. Biochar is mainly used as a soil conditioner, which has been found to be effective in carbon sequestration thereby reducing net carbon dioxide emissions (Hung et al., 2017).

\section{CONCLUSIONS}

Post-fermentation process has a high potential as indicator of digestate value. Before land application it is worth to test if digestate from methane fermentation might still produce methane. During optimization of organic compounds loading it turn out that $3 \mathrm{~kg} /\left(\mathrm{m}^{3} \cdot \mathrm{d}\right)$ was too high value and in case of this loading solid retention time should be prolonged.

\section{ACKNOWLEDGEMENTS}

The study was carried out in the framework of the project under program BIOSTRATEG funded by the National Centre for Research and Development No. 1/270745/2/NCBR/2015 "Dietary, power, and economic potential of Sida hermaphrodita cultivation on fallow land".

\section{REFERENCES}

1. Borkowska, H., Molas, R. 2012. Two extremely different crops, Salix and Sida, as sources of renewable bioenergy. Biomass \& Bioenergy, Vol. 36 (1), pp. 234-240. https://doi.org/10.1016/j.biombioe.2011.10.025

2. Chambers, B.J., Taylor, M. 2013. The use of digestate as a substitute for manufactured fertilizer. In: Koress, N.E., O'Kiely, P., Benzie, J.A.H., West, J.S. (eds) Bioenergy production by anaerobic digestion: using agricultural biomass and organic wastes. Routledge (Taylor and Francis Group), New York, pp. 350-374.

3. Cheng, C.L., Lo, Y.C., Lee, K.S., Lee, D.J., Lin, C.Y., Chang, J.S. 2011 Biohydrogen production from lignocellulosic feedstock. Bioresource Technology, Vol. 102(18), pp. 8514-8523. https://doi.org/10.1016/j.biortech.2011.04.059

4. Dhanya, M.S., Prasad, S., Singh, A. 2013. Biogas technology for developing countries: an approach to sustainable development. In: Koress, N.E., O’Kiely, P., Benzie, J.A.H., West, J.S. (eds) Bioenergy production by anaerobic digestion: using agricultural biomass and organic wastes. Routledge (Taylor and Francis Group), New York, pp. 30-45.

5. Drosg, B., 2013. Process monitoring in biogas plants. IEA Bioenergy Task.

6. Forster-Carneiro, T., Perez, M., Romero, U., Sales, D. 2007. Dry-thermophilic anaerobic digestion of organic fraction of the municipal solid waste: focusing on the inoculum sources. Bioresource Technology, Vol. 98, pp. 3195-3203. https://doi.org/10.1016/j.biortech.2006.07.008

7. Frigon, J.C., Guiot, S.R. 2010. Biomethane production from starch and lignocellulosic crops: a comparative review. Biofuels, Bioproducts and Biorefining, Vol. 4, pp. 447-458. https://doi.org/10.1002/bbb.229

8. Hung, C.Y., Tsai, W.T., Chen, J.W., Lin, Y.Q., Chang, Y.M. 2017. Characterization of biochar prepared from biogas digestate. Waste Management, Vol. 66, pp. 53-60.https://doi.org/10.1016/i.wasman.2017.04.034

9. Khanal, S.K. 2008. Anaerobic biotechnology for bioenergy production: principles and application. Wiley-Blackwell. https://doi.org/10.1002/9780813804545

10. Klimiuk, E., Pokój, T., Budzyński, W., Dubis, B. 2010. Theorectical and observed biogas production from plant biomass of different fibre contents. Bioresource Technology, Vol. 101 (24), pp. 9527-9535. https://doi.org/10.1016/j.biortech.2010.06.130

11. Le Hyaric, R., Chardin, C., Benbelkacem, H., Bollon, J., Bayard, R., Escudié, R., Buffière, P. 2011. Influence of substrate concentration and moisture content on the specific methanogenic activity of dry mesophilic municipal solid waste digestate spiked with propionate. Bioresource Technology, Vol. 102 (2), pp. 822-827. https://doi.org/10.1016/j.biortech.2010.08.124

12. Zheng, Y., Zhao, J., Xu, F.Q., Li, Y. 2014. Pretreatment of lignocellulosic biomass for enhanced biogas production. Progress in Energy and Combustion Science, Vol. 42, pp. 35-53. https://doi.org/10.1016/j.pecs.2014.01.001 